\title{
PHYSIOLOGICAL TRAITS OF THE INITIAL GROWTH IN RAINFED RICE PLANTS IN RESPONSE TO SEED TREATMENT WITH MICRONUTRIENTS
}

\author{
CARACTERÍSTICAS FISIOLÓGICAS DE CRESCIMENTO INICIAL DE PLANTAS DE \\ ARROZ DE SEQUEIRO EM RESPOSTA AO TRATAMENTO DE SEMENTES COM \\ MICRONUTRIENTES
}

\author{
Danielli OLSEN¹; Tiago PEDÓ ${ }^{2}$; Geison Rodrigo AISENBERG ${ }^{1}$; Tiago Zanatta AUMONDE ${ }^{3}$; \\ Francisco Amaral VILLELA ${ }^{3}$ \\ 1. Pós Graduando do PPG C\&T de Sementes. Departamento de Fitotecnia/FAEM. Universidade Federal de Pelotas - UFPel, Pelotas - \\ RS, Brasil; 2. Professor, Pós-Doc do PPG C\&T de Sementes, Bolsista CAPES, FAEM/UFPel. tiago.pedo@ gmail.com; 3.Professor \\ Doutor, PPG C\&T de Sementes, DFt/FAEM/UFPel.
}

\begin{abstract}
The study aimed to analyze the effect of seed treatment with micronutrients on the growth of rainfed rice plants. Treatments consisted in the absence of micronutrient application, single applications or a combination of five micronutrients applied to seeds: compound Zinc + Molybdenum (Mo 2.3, Zn 3.5\% w/v) in a dose of 2 mL kg seed; Copper + Molybdenum + Zinc + Manganese (6.7 Cu, 3.2 Mo, $15 \mathrm{Zn} ; 9.4 \% \mathrm{Mn}$ w/v) at a dose of $3 \mathrm{~mL} \mathrm{~kg} \mathrm{~kg}^{-1}$ seed; Zinc $(100 \% \mathrm{Zn} \mathrm{p} / \mathrm{v})$ at a dose of $2 \mathrm{~mL} \mathrm{~kg}^{-1}$ seed, Manganese $\left(50 \% \mathrm{Mn}\right.$ w/v) at a dose of $2 \mathrm{ml} \mathrm{kg}^{-1}$ seed, Boron $(3 \% \mathrm{~B} \mathrm{w} / \mathrm{v})$ at a dose of $3 \mathrm{~mL} \mathrm{~kg}$. Plants were collected at, three, seven and eleven days after emergence with readings of leaf area and estimates for dry weight of shoots and roots. From these data calculations were derived for the total plant dry mass, shoot/root ratio, ratio of leaf area to leaf mass and the specific leaf area. The compound mixture of $\mathrm{Cu}+\mathrm{Mo}+\mathrm{Zn}+\mathrm{Mn}$ provided the highest seedling dry matter accumulation and highest leaf area, while single zinc applications stimulated the accumulation of root dry mass. Seed treatment with micronutrients provides better performance for the initial growth in rainfed rice plants.
\end{abstract}

KEYWORDS: Oryza sativa. Micronutrients. Leaf area. Dry matter.

\section{INTRODUCTION}

Rice (Oryza sativa L.) is a major agricultural crop for the Brazilian agriculture scenario, due to its high productivity and cultivated area. It is a highly versatile crop that adapts to a wide range of soil and climate conditions, providing $20 \%$ carbohydrates and $15 \%$ proteins (EMBRAPA, 2005). In the 2012/2013 cropping season the national production of this crop reached 11.8 million tons, with an average yield of $2186 \mathrm{~kg} \mathrm{ha}^{-1}$ (CONAB, 2013), officially considered as a lowperformance season, due to the species' high yield potential.

Seed treatment is a viable alternative for cropping regions with acidic soils and low micronutrient concentrations (LOPES; SOUZA, 2001). Micronutrients are essential elements for plant development, due to their role on metabolism functions, acting as catalysts of diverse physiological and hormonal processes. Moreover, they act as cofactors and are constituent part of many enzymes acting during seed germination (DINIZ et al., 2007).

The application of micronutrients through seed treatment is a practical and efficient way of correcting deficiencies, due to low seedling demand for micronutrients (RIBEIRO; SANTOS, 1996).
Several studies were conducted to evaluate the effects of micronutrient application via seed treatment, for common beans (CICERO et al., 1999.) and soybean (BROCH; FERNANDES, 1999). However, there is no work relating the effect of micronutrient application on the physiological performance of rainfed rice seedlings.

The evaluation of the initial stages of plant growth allows for inference on the morphophysiological processes in response to different crop conditions; being important for the study of adaptation and physiological performance of plants under different environmental, management and cultivation conditions (AUMONDE et al., 2011) as well as for the description of plant performance in situations of stress or unfavorable environmental conditions (LOPES et al., 1987). In regard to the previous comments, the evaluation of plants during the initial stages of growth constitutes an important tool to assess under field or controlled conditions the performance of plants originated from seeds treated with micronutrients.

Thus, the objective of this study was to evaluate the effect of seed treatment with micronutrients on the physiological performance of initial growth of rainfed rice plants. 


\section{MATERIAL AND METHODS}

The experiment was performed in a chapelstyle greenhouse, located on coordenates latitude $31^{\circ} 48^{\prime} 15^{\prime \prime} \mathrm{S}$ and longitude $52^{\circ} 24^{\prime} 55^{\prime \prime} \mathrm{W}$. The analyses were performed at the seed testing laboratory from the postgraduate program Seed Science \& Technology, Universidade Federal de Pelotas, Capão do Leão-RS.

The treatments involved a check (absence of micronutrient application), and individual or combined application of five micronutrients to seeds: Zinc compound + Molybdenum (Mo 2.3, Zn $3.5 \% \mathrm{w} / \mathrm{v})$ in a dose of $2 \mathrm{~mL} \mathrm{~kg}^{-1}$ seed; Copper + Molybdenum + Zinc + Manganese $(6.7 \mathrm{Cu}, 3.2 \mathrm{Mo}$, $15 \mathrm{Zn} ; 9.4 \% \mathrm{Mn} w / \mathrm{v})$ at a dose of $3 \mathrm{~mL} \mathrm{~kg}^{-1}$ seed; Zinc $(100 \% \mathrm{Zn} \mathrm{p} / \mathrm{v})$ at a dose of $2 \mathrm{~mL} \mathrm{~kg}^{-1}$ seed, Manganese $(50 \% \mathrm{Mn} \mathrm{w} / \mathrm{v})$ at a dose of $2 \mathrm{ml} \mathrm{kg}^{-1}$ seed, Boron ( $3 \% \mathrm{~B} \mathrm{w} / \mathrm{v})$ at a dose of $3 \mathrm{~mL} \mathrm{~kg}^{-1}$. The dosage was that recommended by the manufacturer for individual or combined application.

Rice seeds were sown in polyethylene trays filled planosoil previously corrected according to analysis results and recommendations (CQFS, 2004). Irrigation performed as needed, according to the species' water requirements and the emergence of plants in the greenhouse was determined from two hundred seeds per treatment, with four replicates of 50 seeds each, sown into the polyethylene trays containing planosoil. The evaluations were performed until the twenty-first day after sowing.

For emergency were used 400 seeds per treatment, divided into samples of 50 seeds and sown in plastic trays containing as substrate soil classified as albaqualf. The evaluation was performed on the twentieth day after sowing and the results expressed as a percentage of seedlings.

The initial growth was evaluated from 10 seedlings per replicate, collected on the third, seventh and eleventh days after emergence (DAE), and separated into their component parts (roots, stems, and leaves). The leaf area $\left(\mathrm{A}_{\mathrm{f}}\right)$ was determined with a Licor LI-3100 area meter and expressed in square centimeters. To estimate seedling dry matter, all plant parts were oven dried (draft) at $70 \pm 2{ }^{\circ} \mathrm{C}$ for $72 \mathrm{~h}$. The dry mass of shoots $\left(\mathrm{W}_{\mathrm{PA}}\right)$ and roots $\left(\mathrm{W}_{\mathrm{R}}\right)$ was obtained using a precision scale and the results expressed in milligrams per organ; the total dry mass $\left(\mathrm{W}_{\mathrm{t}}\right)$ was estimated by the sum of $\mathrm{W}_{\mathrm{PA}}$ and $\mathrm{W}_{\mathrm{R}}$ and the shoot to root ratio through $\left(\mathrm{P}_{\mathrm{w}}\right)$ equation (1).

$$
\text { (1) } P_{w}=\frac{W_{P A}}{W_{R}}
$$

The leaf area ratio $\left(\mathrm{F}_{\mathrm{a}}\right)(2)$, the leaf mass ratio $\left(\mathrm{F}_{\mathrm{w}}\right)$ (3) and specific leaf area $\left(\mathrm{S}_{\mathrm{a}}\right)$ (4), according to Radford (1967), where: $\mathrm{W}_{\mathrm{PA}}=$ shoot dry matter; $\mathrm{W}_{\mathrm{R}}=$ root dry matter; $\mathrm{W}_{\mathrm{f}}=$ leaf dry matter; $\mathrm{W}_{\mathrm{t}}=$ total dry matter and $\mathrm{A}_{\mathrm{f}}=$ leaf area. Were determined by equations:

$$
\begin{aligned}
& \text { (2) } F_{a}=\frac{A_{f}}{W_{t}} \\
& \text { (3) } F_{w}=\frac{W_{f}}{W_{t}} \\
& \text { (4) } S_{a}=\frac{A_{f}}{W_{f}}
\end{aligned}
$$

The experimental design was a randomized block design with six treatments and four replications. Data was subjected to analysis of variance and if significant at 5\%, were compared by Tukey test at $5 \%$ probability level.

\section{RESULTS AND DISCUSSION}

Seedling emergence was unaffected by seed treatment, in average of $85 \%$. Initial seedling growth showed significant differences between the check treatment and the rest, for days three, seven and eleven after emergence, respectively (Figure 1).

Shoot dry matter $\left(\mathrm{W}_{\mathrm{PA}}\right)$ on the third day after emergence (DAE) was higher for seedlings originating from seeds treated with Copper + Molybdenum + Zinc + Manganese and similar among the other treatments (Figure 1). Seedlings from seeds treated to Zinc showed, on the seventh DAE, a lower shoot dry matter allocation compared to the product comprising $\mathrm{Cu}+\mathrm{Mo}+\mathrm{Zn}+\mathrm{Mn}$. On the eleventh DAE no difference among treatments on shoot dry matter allocation was observed.

The highest seedling response to the product containing $\mathrm{Cu}+\mathrm{Mo}+\mathrm{Zn}+\mathrm{Mn}$, occurred on DAE 3 and 7 , can be attributed to the effect of molybdenum on the plants' metabolism, favoring nitrate assimilation (PEREIRA et al., 2012). Similar data for shoot dry matter of plants originated both from treated and non-treated seeds were obtained by Diniz et al. (2006).

Root dry matter $\left(\mathrm{W}_{\mathrm{R}}\right)$ was highest for treatment $\mathrm{Cu}+\mathrm{Mo}+\mathrm{Zn}+\mathrm{Mn}$, followed by that with $\mathrm{Zn}+\mathrm{Mo}, \mathrm{Mg}$ and $\mathrm{B}$, which do not differ to DAE 3 (Figure 1b). Analyzing the effect of the seed treatments on DAE 7, the highest dry matter allocation was that of seedlings under the effect of $\mathrm{Mg}$ followed by $\mathrm{B}, \mathrm{Zn}, \mathrm{Zn}+\mathrm{Mo}$ and the check treatment. On the eleventh DAE the highest dry matter allocation was recorded for plants originated from seeds treated to $\mathrm{Zn}, \mathrm{Mn}$ and B. Seedlings 
under the effect of $\mathrm{Cu}+\mathrm{Mo}+\mathrm{Zn}+\mathrm{Mn}$ showed

similar carbon allocation to those on $\mathrm{Mn}$ and $\mathrm{B}$.

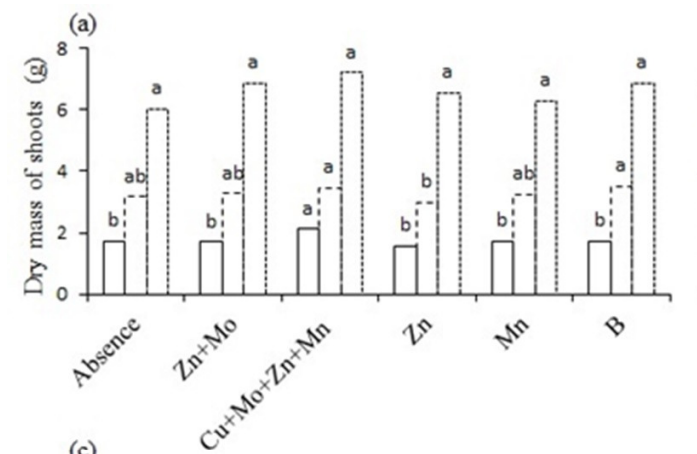

(b)
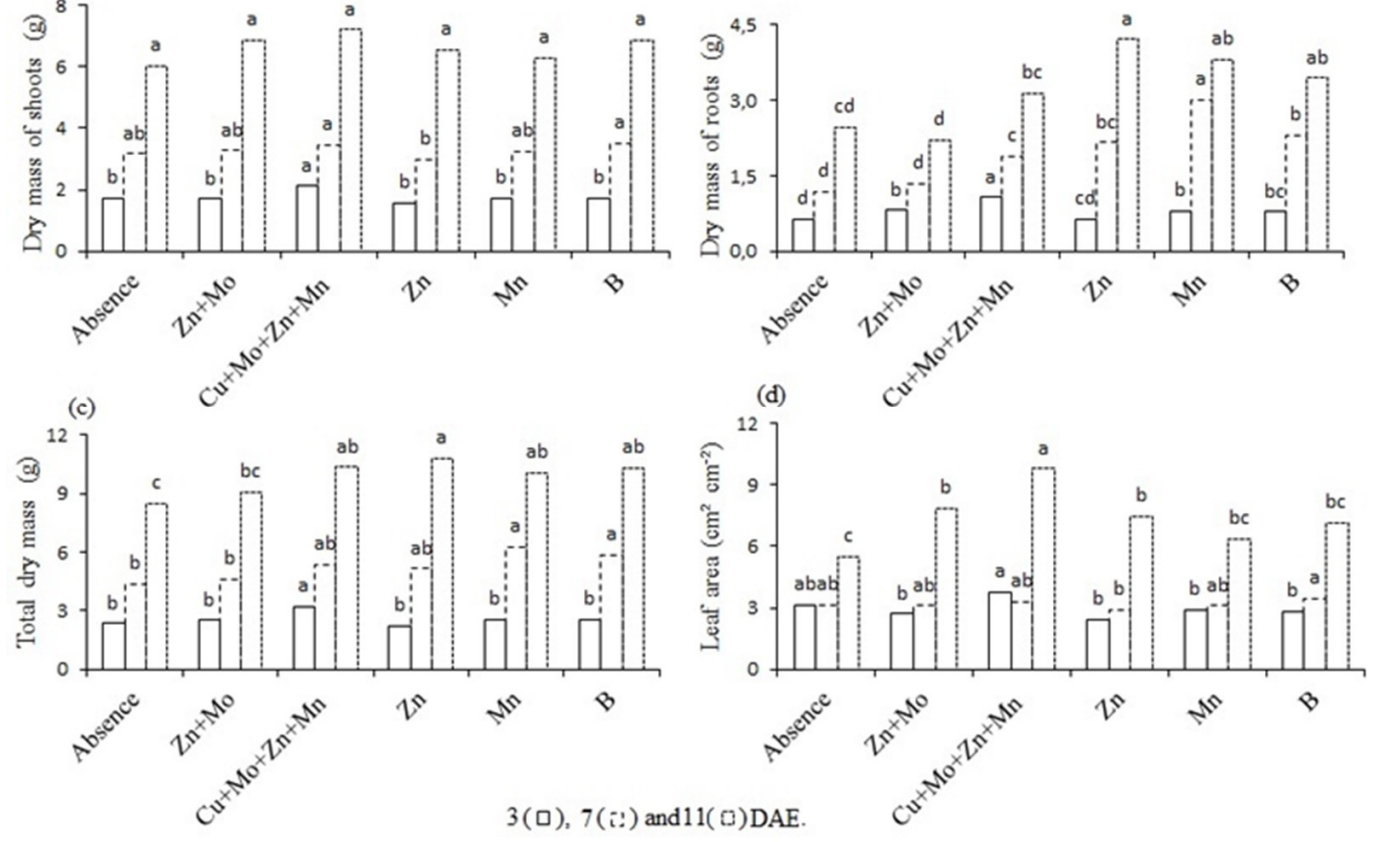

Figure 1. Dry matter of shoots (a), roots (b), total (c) and leaf area (d) of rainfed rice seedlings originated from seeds treated to micronutrients on the the third, seventh and eleventh days after emergence (DAE). Means on the same line followed by the same letter within each evaluation period do not differ by Tukey test at $5 \%$ level.

The lower initial rate of dry matter accumulation can be related to the influence of micronutrient concentration, affecting seed vigor. Luchese et al. (2004) observed a similar trend when assessing the emergence and copper absorption by corn seedlings. Upon evaluating the effect of zinc, boron and copper on the vigor of irrigated rice seeds, OHSE et al. (2000/2001) observed negative effects of these nutrients.

The total seedling dry matter $\left(\mathrm{W}_{\mathrm{t}}\right)$ accumulation of rainfed rice plants was higher those treated to $\mathrm{Cu}+\mathrm{Mo}+\mathrm{Zn}+\mathrm{Mn}$ than for the rest (Figure 1c). On DAE seven higher dry matter allocation was recorded for nutrients $\mathrm{Mn} ; \mathrm{B} ; \mathrm{Cu}+$ $\mathrm{Mo}+\mathrm{Zn}+\mathrm{Mn}$ and $\mathrm{Zn}$, while, a lower allocation occurred when combining $\mathrm{Zn}+\mathrm{Mo}$ and for the check treatment. Similarly, on the eleventh DAE higher rates for carbon allocation occurred for seedlings treated to $\mathrm{Zn} ; \mathrm{Cu}+\mathrm{Mo}+\mathrm{Zn}+\mathrm{Mn} ; \mathrm{B}$ and $\mathrm{Mn}$ while the lowest rates of carbon allocation values were recorded for the check treatment.

This results show the benefit of the application of micronutrients via seed treatment for the rainfed rice plants. Zinc has a role in amino acid synthesis and enzyme activation (FUNGUETTO, 2007) while Molybdenum is associated to the assimilation of inorganic nitrogen and the promotion of protein and enzyme biosynthesis (POSSENTI; VILLELA, 2010).

During the initial stages of seedling growth (DAE 3), leaf area $\left(A_{f}\right)$ was higher for seedlings from seeds treated to $\mathrm{Cu}+\mathrm{Mo}+\mathrm{Zn}+\mathrm{Mn}$ as well as those from the check treatment, compared to seedlings under the other treatments (Figure 1d). On the seventh DAE, the highest $\mathrm{A}_{\mathrm{f}}$ value was obtained for seedlings originated from seeds treated with boron and the lower value was for those treated with $\mathrm{Zn}$. On the eleventh DAE, $\mathrm{A}_{\mathrm{f}}$ was higher in seedlings under the effect of $\mathrm{Cu}+\mathrm{Mo}+\mathrm{Zn}+\mathrm{Mn}$ with the lowest values occurring in all of the other treatments.

Any increase in leaf area favors the increase of the photosynthetic apparatus of plants, which affects the production of assimilates (AUMONDE et al., 2011; PEDÓ et al., 2013). The effects of this micronutrients can be related to the carbohydrate metabolism, sugar transport and the formation of cell walls, cell division and development of plant tissues (BORKET, 1989).

The shoot/root ratio $\left(\mathrm{P}_{\mathrm{w}}\right)$ on the third DAE, was higher in plants originated from untreated seeds and of those treated to $\mathrm{Zn}$ (Figure 2a). On the seventh DAE, seeds from the check treatment and seeds treated with $\mathrm{Zn}+$ Mo showed higher values 
than $\mathrm{P}_{\mathrm{W}}$. Nevertheless, on the eleventh DAE the higher value of $\mathrm{P}_{\mathrm{W}}$ was obtained by seedlings treated to $\mathrm{Zn}+\mathrm{Mo}$, while the lowest $\mathrm{P}_{\mathrm{W}}$ was recorded for seedlings from the Mn treatment.

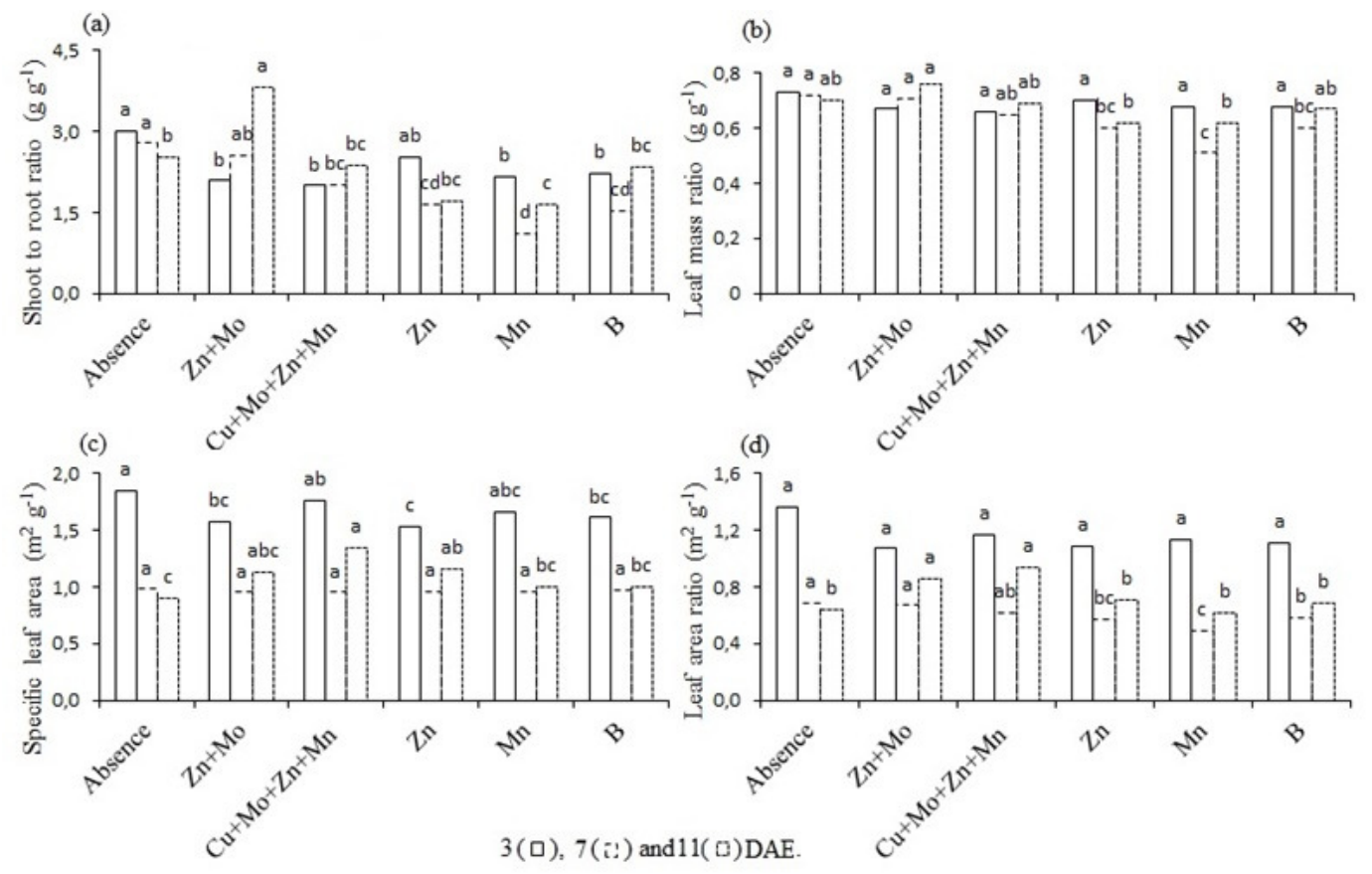

Figure 2. Shoot to root ratio (a), leaf mass (b), specific leaf area (c) and the leaf area ratio (d) of rainfed rice plants originated from seeds treated to micronutrients, and assessed on the third, seventh and eleventh days after emergence. Means on the same line followed by the same letter within each evaluation period do not differ by Tukey test at $5 \%$ level.

$\mathrm{P}_{\mathrm{w}}$ results indicate lower shoot dry matter accumulation compared to that of roots, mainly for seedlings of the check treatment. Working with lettuce seeds treated to different micronutrient concentrations, Diniz et al. (2007) observed that the endo- $\beta$-mannanase enzyme showed enhanced activity in the absence of micronutrients, while increasing concentrations of the latter resulted in lower levels of enzyme activity.

The leaf mass ratio $\left(\mathrm{F}_{\mathrm{W}}\right)$ on the third DAE did not differ among treatments (Figure $2 b$ ). On the seventh DAE, $F_{W}$ was highest for seedlings under treatments without micronutrients, $\mathrm{Zn}+\mathrm{Mo}$ and $\mathrm{Cu}$ $+\mathrm{Mo}+\mathrm{Zn}+\mathrm{Mn}$. This observation was also recorded on the eleventh DAE, for seedlings of seeds treated to $\mathrm{Zn}$ and $\mathrm{Mn}$, who exhibited lower values of $F_{W}$. Higher values of $F_{W}$ indicate a higher dry matter allocation to leaves (PEDÓ et al., 2013).

As for the specific leaf mass $\left(S_{a}\right)$, on the third DAE the higher values were achieved in plants originated from seeds not treated to micronutrients $\mathrm{Cu}+\mathrm{Mo}+\mathrm{Zn}+\mathrm{Mn}$ and $\mathrm{Mn}$. The lower values of $\mathrm{S}_{\mathrm{a}}$ were observed for plants under the effect of $\mathrm{Zn}$ (Figure 2c). On the seventh DAE no significant differences were observed among treatments. Nevertheless, when analyzing the growth on the eleventh DAE, the highest values of $S_{a}$ were achieved by seedlings from treatments $\mathrm{Cu}+\mathrm{Mo}+$ $\mathrm{Zn}+\mathrm{Mn}, \mathrm{Zn}+\mathrm{Mo}$ and $\mathrm{Zn}$. The specific leaf area relates the leaf surface area with dry weight from these leaves, so that lower values of $S_{a}$ can be explained by the reduction or standstill of the leaf area expansion in relation to its leaf dry weight increase (AUMONDE et al., 2011).

The leaf area ratio $\left(\mathrm{F}_{\mathrm{a}}\right)$ on the third DAE did not differ across treatments (Figure 2d). On the seventh DAE, the higher values were obtained on plants originated from non-treated plants with micronutrients, $\mathrm{Zn}+\mathrm{Mo}$ and $\mathrm{Cu}+\mathrm{Mo}+\mathrm{Zn}+\mathrm{Mn}$, while the lowest $F_{a}$ value occurred in plants under the effect of Magnesium, which did not differ with seedlings from the Zinc treatment. On the eleventh DAE the highest levels of $F_{a}$ were achieved by seedlings from the $\mathrm{Zn}+\mathrm{Mo}$ and $\mathrm{Cu}+\mathrm{Mo}+\mathrm{Zn}+$ Mn treatments.

Higher initial levels of $F_{a}$ imply a plant strategy favoring the formation of leaf area to enhance photosynthesis (PEDÓ et al., 2013). According to Borket (1989), zinc is the micronutrient related to carbohydrate, protein and RNA metabolism, all of which support plant growth. Within this context, any $F_{a}$ growth reflects the growth enhancement by the micronutrients. 
These results indicate that the compound containing $\mathrm{Cu}+\mathrm{Mo}+\mathrm{Zn}+\mathrm{Mn}$ provided a greater accumulation of dry matter and the highest leaf area values. On the other hand plants originated from seeds treated with the compound $\mathrm{Zn}+$ Mo showed higher shoot to root ratio. Zinc stimulated the accumulation of root dry matter, while Manganese favored the leaf area to leaf mass ratio on the third DAE and Boron enhanced the total dry matter accumulation after the seventh and eleventh days after emergence, respectively.

\section{CONCLUSION}

Seed treatment with micronutrients favors the initial growth of rainfed rice seedlings, with variable results according to the growth stage and the specific mineral nutrient.

RESUMO: O trabalho objetivou analisar o efeito do tratamento de sementes com micronutrientes no crescimento inicial de plantas de arroz de sequeiro. Os tratamentos consistiram na ausência de aplicação de micronutrientes e de aplicação isolada ou em combinação de cinco micronutrientes via semente: composto Zinco + Molibdênio (2,3 Mo; 3,5\% Zn p/v) na dose de $2 \mathrm{~mL} \mathrm{~kg}^{-1}$ semente; Cobre + Molibdênio + Zinco + Manganês (6,7 Cu; 3,2 Mo; $15 \mathrm{Zn} ; 9,4 \% \mathrm{Mn} p / v)$ na dose de $3 \mathrm{~mL} \mathrm{~kg}^{-1}$ semente; Zinco (100\% Zn p/v) na dose de $2 \mathrm{~mL} \mathrm{~kg}^{-1}$ semente; Manganês $(50 \% \mathrm{Mn} p / v)$ na dose de $2 \mathrm{~mL} \mathrm{Kg}^{-1}$ semente; Boro $(3 \% \mathrm{~B} / v)$ na dose de $3 \mathrm{~mL} \mathrm{~kg}^{-1}$. As plantas foram coletadas a intervalos regulares de quatro dias após a emergência, aos três, sete e onze dias e determinados os dados primários de área foliar, massa seca de parte aérea e de raiz. A partir dos dados primários foram calculadas a massa seca total, a razão parte aérea/raiz, a razão de área foliar e de massa foliar, e a área foliar específica. O composto contendo $\mathrm{Cu}+\mathrm{Mo}+\mathrm{Zn}+\mathrm{Mn}$ proporcionou maior acúmulo de matéria seca de plântulas e superior área foliar, enquanto, o zinco estimulou o acúmulo de matéria seca na raiz. O tratamento de sementes com micronutrientes proporciona melhor performance de crescimento inicial em plantas em arroz de sequeiro.

PALAVRAS-CHAVE: Oryza sativa. Micronutrientes. Área foliar. Matéria seca.

\section{REFERENCES}

AUMONDE, T. Z.; LOPES, N. F.; MORAES, D. M.; PEIL, R. M. N.; PEDÓ, T. Análise de crescimento do híbrido de mini melancia Smile ${ }^{\circledR}$ enxertada e não enxertada. Interciência, Caracas, v. 36, n. 9, p. 677-681. 2011.

BORKET, C. M. Micronutrientes na planta. In.: BÜLL, L. T.; ROSOLEM, C. A. (Ed.). Interpretação de análise química de solo e planta para fins de adubação. Botucatu: Fundação de Estudos e Pesquisas Agrícolas e Florestais, p.309-329. 1989.

BROCH, D. L.; FERNANDES, C. H. Resposta da soja à aplicação de micronutrientes. Maracaju, MS: Fundação MS, 56p. 1999. (Informativo Técnico 02/99).

CQFS. Manual de adubação e calagem para os Estados do Rio Grande do Sul e Santa Catarina.

Sociedade Brasileira de Ciência do Solo. Comissão de Química e Fertilidade do Solo. 10a . Ed. Porto Alegre, 400p. 2004.

CÍCERO, S. M.; NASCIMENTO, W. M. O.; MIGUEL, M. H.; CARVALHO, M. V.; SMIDERLE, O. J.; MORAES, M. C. Aplicação de micronutrientes e de inoculantes em sementes de feijão: efeitos na produção e na qualidade fisiológica das sementes. Informativo ABRATES, Londrina, v. 9, n. 1/2, p. 97. 1999.

CONAB. Acompanhamento de safra Brasileira: grãos, nono levantamento, julho 2013.<http://www.conab.gov.br/OlalaCMS/uploads/arquivos/13_07_09_09_04_53_boletim_graos_junho_201 3.pdf>. Acesso em: 05 Ago. 2013.

DINIZ, K. A.; OLIVEIRA, J. A.; GUIMARÃES, R. M.; CARVALHO, M. L. M.; MACHADO, J. C. Incorporação de microrganismos, aminoácidos, micronutrientes e reguladores de crescimento em sementes de alface pela técnica de peliculização. Revista Brasileira de Sementes, Londrina, v. 28, n. 3, p. 37-43. 2006. http://dx.doi.org/10.1590/s0101-31222006000300006 
DINIZ, K. A.; SILVA, P. A.; VEIGA, A. D.; ALVIM, P. O.; OLIVEIRA, J. A. Qualidade fisiológica e atividade enzimática de sementes de alface revestidas com diferentes doses de micronutrientes, aminoácidos e reguladores de crescimento. Revista Ciência Agronômica, Fortaleza, v. 38, n. 4, p. 396-400. 2007.

FUNGUETTO, C. I. Tratamento de sementes de grandes culturas com micronutriente zinco, fungicida e polímero. Norte Científico, Boa Vista, v. 2, n. 1, p. 64-75. 2007.

LOPES, A. S.; SOUZA, E. C. A. Filosofias e eficiência de aplicação. In: FERREIRA, M. E. (Ed.). Micronutrientes e elementos tóxicos na agricultura. Jaboticabal: CNPq/Fapesp/Potafos, p. 255-282. 2001.

LOPES, N. F.; OLIVA, M. A.; GOMES, M. M. S.; SOUZA, V. F.; CARDOSO, M. J. Crescimento, morfologia, partição de assimilados e produção de matéria seca do feijão (Phaseolus vulgaris L.) submetido a três densidades do fluxo radiante e dois regimes hídricos. Revista Ceres, Viçosa, v. 34, n. 192, p. 110-124. 1987.

LUCHESE, A. V.; GONÇALVES JUNIOR, A. C.; LUCHESE, E. B.; BRACCINI, M. C. L. Emergência e absorção de cobre por plantas de milho (Zea mays) em resposta ao tratamento de sementes com cobre. Ciência Rural, Santa Maria, v. 24, n. 6, p. 1949-1952. 2004. http://dx.doi.org/10.1590/S0103-84782004000600044

OHSE, S.; MARODIM, V.; SANTOS, O. S.; LOPES, S. J.; MANFRON, P. A. Germinação e vigor de sementes de arroz irrigado tratadas com zinco, boro e cobre. Revista da FZVA, Uruguaiana, v. 7/8, n. 1, p. 4150. 2000/2001.

PEDÓ, T.; AUMONDE, T. Z.; LOPES, N. F.; VILLELA, F. A.; MAUCH, C. R. Análise de crescimento e partição de assimilados em plantas de fisalis submetidas a intervalos de adubação foliar. Semina: Ciências Agrárias, Londrina, v. 34, n. 5, p. 2247-2256. 2013. http://dx.doi.org/10.5433/1679-0359.2013v34n5p2247

PEREIRA, F. R. S.; BRACHTVOGEL, E. L.; CRUZ, S. C. S.; BICUDO, S. J.; MACHADO, C. G.; PEREIRA, J. C. Qualidade fisiológica de sementes de milho tratadas com molibdênio. Revista Brasileira de Sementes, Londrina, v. 34, n. 3, p. 450-456. 2012. http://dx.doi.org/10.1590/S0101-31222012000300012

POSSENTI, J. C.; VILLELA, F. A. Efeito do molibdênio aplicado via foliar e via sementes sobre o potencial fisiológico e produtividade de sementes de soja. Revista Brasileira de Sementes, Londrina, v. 32, n. 4, p. 143150. 2010. http://dx.doi.org/10.1590/S0101-31222010000400016

RADFORD, P. J. Growth analysis formulae: their use and abuse. Crop Science, Madison, v. 7, n. 3, p.171-175. 1967. http://dx.doi.org/10.2135/cropsci1967.0011183X000700030001x

RIBEIRO, N. D.; SANTOS, O. S. Aproveitamento do zinco aplicado na semente na nutrição da planta. Ciência Rural, Santa Maria, v. 26, p. 159-165. 1996. http://dx.doi.org/10.1590/S0103-84781996000100030 